\title{
FORMULASI SEDIAAN LILIN AROMATERAPI DARI EKSTRAK KECOMBRANG (ETLINGERA ELATIOR), SEREH WANGI (CYMBOPOGON NARDUS L.),DAN CENGKEH (SYZYGIUM AROMATICUM)
}

\author{
Hilmarni1 $^{*}$, Suci Fauzana ${ }^{1}$, Riki Ranova ${ }^{1}$ \\ ${ }^{1}$ Akademi Farmasi Imam Bonjol Bukittinggi \\ email:hilmarniafzan@gmail.com
}

\begin{abstract}
Aromatherapy is an alternative treatment method derived from volatile plant materials. Aromatherapy can provide a calming effect, refreshing, stabilizing the body and soul and maintaining beauty. The chemical components of Kecombarang, Citronella and Cloves can be used as raw materials for various products such as aromatherapy products. The purpose of this study was to make a wax formula from extracts of Kecombrang, Citronella grass and cloves as aromatherapy candles. The preparation of wax preparations was carried out by adding the extract obtained from the percolation and soxhletation processes into a mixture of solid paraffin wax base and stearic acid. The results showed that candles with extracts of Kecombrang, Citronella grass and Cloves could be used as aromatherapy candle preparations because they met the physical evaluation requirements, namely organoleptic test, burn time test, melting point test and hedonic test.
\end{abstract}

Keywords:Kecombrang, Citronella grass, Cloves, Aromatherapy Candles

\begin{abstract}
ABSTRAK
Aromaterapi merupakan suatu metode pengobatan alternatif yang berasal dari bahan tanaman yang mudah menguap/ minyak atsiri.Aromaterapi dapat memberikan efek menenangkan, menyegarkan, menstabilkan jiwa dan raga serta menjaga kecantikan.Komponen kimia dalam Kecombarang,Sereh Wangi dan Cengkeh dapat digunakan sebagai bahan baku untuk berbagai produk seperti produk aromaterapi. Tujuan dari penelitian ini adalah untuk membuat formula lilin dari ekstrak Kecombrang, sereh wangi dan cengkeh sebagai lilin aromaterapi.Pembuatan sediaan lilin dilakukan dengan penambahan ekstrak yang diperoleh dari proses perkolasi dan sokletasi kedalam campuran basis lilin parafin padat dan asam stearat. Hasil penelitian diperoleh lilin dengan ekstrak Kecombrang, Sereh Wangi dan Cengkeh dapat dijadikan sediaan lilin aromaterapi karena memenuhi syarat evaluasi fisik yaitu uji organoleptis, uji waktu bakar, uji titik leleh dan uji hedonik.
\end{abstract}

Kata kunci:Kecombrang, Sereh Wangi, Cengkeh, Lilin aromaterapi

\section{PENDAHULUAN}

Indonesia merupakan Negara yang kaya akan sumber daya alam hayati sehingga dijuluki sebagai Negara agraris. Salah satunya adalah tanaman penghasil minyak atsiri.Indonesia adalah 
Negara yang menghasilkan 40 - 50 jenis tanaman penghasil minyak atsiri dari 80 jenis minyak atsiri yang di perdagangkan di dunia. Sumber dari minyak atsiri tersebut berasal dari bagian tanaman akar, batang, daun, bunga, buah dan lain sebagainya (Zuddin, R, R, dkk., 2019).

Untuk pemakaiaan luar, sebagai pestisida serta melalui pernapasan seperti parfum atau keperluan aromaterapi (Kardinan, A, 2005).Aromaterapi merupakan suatu metode pengobatan alternatif yang berasal dari bahan tanaman yang mudah menguap/ minyak atsiri.Aromaterapi dapat memberikan efek menenangkan, menyegarkan, menstabilkan jiwa dan raga serta menjaga kecantikan.Bentuk aromaterapi sendiri bermacam-macam, misalnya penguapan, parfum, pijatan serta lilin (Novita, W, 2009).

Lilin pada umumnya digunakan sebagai pengganti lampu, namun lilin bisa juga dibuat dengan tujuan tertentu misalnya lilin untuk aromaterapi. Pada pembuatannya ditambahkan minyak atsiri yang berkhasiat untuk pengobatan, penyegar ruangan dan lainnya (Yuliani, S, dkk.,2012).

Bunga kecombrang (Etlingera elatior) adalah tanaman yang bisa digunakan sebagai aromaterapi karena mengandung minyak atsiri (Permadi, A, 2008). Sereh wangi (Cymbopogon nardus $L$.) juga merupakan tanaman yang menghasilkan minyak atsiri dengan mutu terbaik dari jenis lain, karena mengandung $80-90 \%$ total geraniol dan 30-45\% sitronelal. Komponen kimia dalam minyak sereh wangi cukup komplek, namun komponen terpenting adalah sitronellal, sitronellol dan geraniol. Ketiga komponen tersebut menentukan intensitas bau harum (Bota, W, dkk., 2015). Cengkeh (Syzygiumaromaticum) mengandung senyawa yang paling penting yaitu eugenol.Senyawa eugenol merupakan senyawa dengan aroma menyegarkan dan pedas.seperti bunga cengkeh kering yang memberikan aroma khas pada minyak cengkeh. Sehingga banyak digunakan sebagai bahan baku untuk berbagai produk seperti obat sakit gigi, cologne, produk aromaterapi dan lain sebagainya (Towaha, J, 2012)

Berdasarkan uraian diatas, penelitian ini dibuat bertujuan untuk membuat dan memperoleh formula lilin dari ekstrak bunga kecombrang (Etlingera elatior), sereh wangi (Cymbopogon nardus L.) ,dan cengkeh (Syzygiumaromaticum) sebagai lilin aromaterapi. Dan dari hasil penelitian ini diharapkan dapat memberikan manfaat dan informasi tentang formulasi lilin aromaterapi dari ekstrak bunga kecombrang, sereh wangi dan cengkeh.

\section{BAHAN DAN METODA}

\section{Alat dan Bahan}

Alat yang di gunakan dalam penelitian ini adalah terdiri dari satu set alat rotary evaporator, soxhlet, percolator, botol gelap, kapas, gelas ukur, timbangan digital, cetakan lilin, vial, cawan uap, batang pengaduk, korek api, stopwatch, pipa kapiler, beaker glass, thermometer, kawat, penangas air, gunting, pisau.

Bahan yang digunakan dalam penelitian ini adalah ekstrak kecombrang, ekstrak sereh wangi, ekstrak cengkeh, paraffin padat, asam stearat, $\mathrm{N}$ - heksan, sumbu lilin.

\section{Metoda}

1. Penyiapan Sampel

a. Kecombrang (Etlingera elatior) diambil di daerah Nagari Mahat Kabupaten 50 Kota, sebanyak 1,2 kg di sortasi basah, kemudian di cuci dengan air mengalir hingga bersih. Bunga yang sudah bersih di rajang halus dan dilakukan penyarian ekstrak dengan cara perkolasi.

b. Daun sereh wangi (Cymbopogon nardus L.) diambil di Bukittinggi, sebanyak $1 \mathrm{~kg}$ di sortasi basah, kemudian di rajang halus dan dilakukan penyarian ekstrak dengan cara perkolasi.

c. Cengkeh (Syzygium aromaticum) diambil di daerah Nagari Mahat Kabupaten 50 Kota, sebanyak 350 gram di sortasi basah kemudian di cuci dengan air mengalir hingga bersih. 
Bunga cengkeh yang sudah bersih di rajang halus dan dan dilakukan penyarian ekstrak dengan cara sokletasi.

2. Formulasi Sediaan Lilin Aromaterapi

Minyak atsiri yang ditambahkan dalam pembuatan sediaan lilin aromatik tidak lebih dari 4 $\%$.Pada pembuatan lilin aromaterapi ini hanya menggunakan 1 konsentrasi ekstrak. Formula lilin aromaterapi yang dibuat ada 4 yaitu F0 (Basis), F1 (ditambahkan ekstrakKecombrang 1 $\%$ ), F2 (ditambahkan ekstrak Sereh Wangi $1 \%$ ), F3 (ditambahkan ekstrak Cengkeh $1 \%$ ) (Djarot, P, dkk., 2019). Formula yang digunakan untuk membuat lilin aromatik dalam penelitian ini adalah sebagai berikut :

Tabel1. Formulasi sediaan

\begin{tabular}{lccccc}
\hline \multirow{2}{*}{\multicolumn{1}{c}{ BAHAN }} & \multicolumn{5}{c}{ FORMULA } \\
\cline { 2 - 6 } & F0 & F1 & F2 & F3 & Kegunaan \\
\hline Ekstrak Kecombrang & 0 & 1 & 0 & 0 & Zat aktif \\
\hline Ekstrak Sereh Wangi & 0 & 0 & 1 & 0 & Zat aktif \\
\hline Ekstrak Cengkeh & 0 & 0 & 0 & 1 & Zat aktif \\
\hline Paraffin Padat & 75 & 74 & 74 & 74 & Basis \\
\hline Asam Stearat & 25 & 25 & 25 & 25 & Basis \\
\hline Total & 100 & 100 & 100 & 100 & \\
\hline
\end{tabular}

3. Pembuatan Lilin Aromaterapi

a. Dengan memanaskan asam stearat dan parafin secara terpisah.

b. Campurkan parafin cair dengan asam stearat cair dalam beaker galss sambil diaduk hingga rata.

c. Selanjutnya masukkan ekstrak Kecombrang, Sereh wangi, dan Cengkeh sesuai takaran masing-masing formula.

d. Lilin cair selanjutnya dituangkan kedalam cetakan yang masing-masing sudah diberi sumbu.

e. Kemudian biarkan sampai mengeras pada suhu ruangan dan terbentuk lilin aromatik yang diinginkan (Djarot, P, dkk., 2019).

4. Evaluasi Sediaan Lilin Aromaterapi

Setelah lilin aromaterapi dibuat kemudian dilakukan uji evaluasi fisik sediaan yang meliputi uji organoleptik seperti warna dan aroma, uji kualitas lilin berupa titik leleh dan waktu bakar, dan uji hedonik atau kesukaan (Zuddin, R, R, dkk., 2019).

\section{HASIL DAN PEMBAHAN}

Dari penelitian mengenai formulasi sediaan lilin aromaterapi dari ekstrak Kecombrang (Elingera elatior), sereh wangi (Cypbopogon nardus L.), dan cengkeh (Syzygium aromaticum) didapatkan hasil sebagai berikut :

1. Ekstrak Kecombrang (Etlingera elatior) berbentuk cairan kental, berwarna kecoklatan, berbau khas kecombrang. Perolehan ekstrak dari 1,2 kg Kecombrang sebanyak 1,1 g. Ekstrak sereh wangi (Cymbopogon nardus $L$ ) berbentuk cairan kental, berwarna hijau, berbau khas sereh wangi. Perolehan ekstrakdari $1 \mathrm{~kg}$ sereh wangi sebanyak 1,48 g. Ekstrak cengkeh (Syzygium aromaticum) berbentuk cair, berwarna coklat, berbau khas cengkeh. Perolehan ekstrakdari 350 
g cengkeh segar sebanyak 12 g. Skrining fitokimia masing-masing ekstrak terlampir pada tabel 2 .

Tabel 2. Skrining fitokimia ekstrak

\begin{tabular}{lccccccc}
\hline \multirow{2}{*}{ Bahan aktif } & \multicolumn{7}{c}{ Skrining Fitokimia } \\
\cline { 2 - 8 } & Alkaloid & Flavonoid & Saponin & Terpenoid & Fenolik & Steroid \\
\hline Ekstrak Kecombrang & - & + & + & - & - & + \\
\hline Ekstrak Sereh Wangi & + & + & + & - & - & - \\
\hline Ekstrak Cengkeh & - & + & - & - & - & + \\
\hline
\end{tabular}

2. Pemeriksaan organoleptis semua sediaan berbentuk padat. Masing-masing formula memiliki aroma yang berbeda, F0 tidak memiliki aroma, F1 aroma Kecombrang, F2 aroma Sereh wangi, F3 aroma Cengkeh. Semua formula memiliki warna yang tidak jauh berbeda, F0 berwarna putih, F1 berwarna putih, F2 berwarna hijau, F3 berwarna putih.

3. Pemeriksaan waktu bakar lilin didapatkan hasil waktu berkisar antara 1 jam 27 menit sampai 1 jam 59 menit.

4. Uji titik leleh menunjukkan bahwa titik leleh masing-masing formula lilin berkisar antara $48^{0}$ $\mathrm{C}-51^{0} \mathrm{C}$.

5. Uji hedonik/ kesukaan dilakukan terhadap 25 orang panelis dengan hasil sesuai gambar 1 .

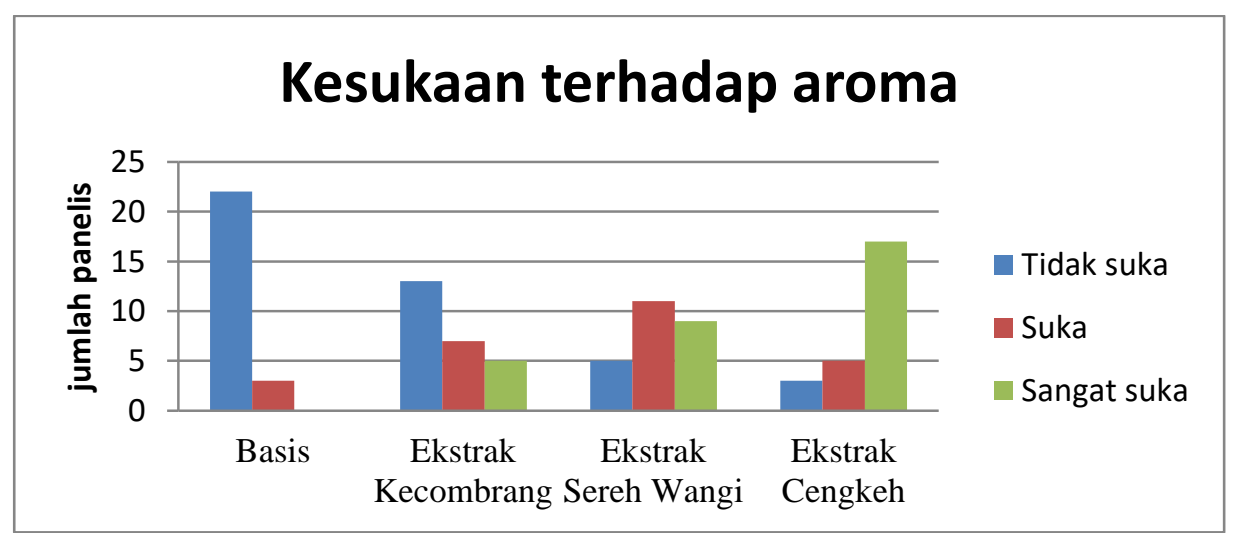

Gambar 1. Grafik Kesukaan Panelis terhadap Aroma

Pada penelitian ini digunakan sampel segar bunga kecombrang yang diambil di daerah Nagari Mahat Kab. 50 Kota. Sebelumnya telah dilakukan Uji Identifikasi sampel di Herbarium Universitas Andalas yang diketahui memiliki nama spesies Etlingera elatior. Kecombrang segar ditimbang sebanyak $1,2 \mathrm{~kg}$ dan dirajang kemudian masukkan kedalam perkolator lalu dibasahi dengan pelarut n-heksan sebanyak 1 liter dan lakukan perkolasi sebanyak 5 kali pengulangan. Filtrat yang didapat di uapkan dalam rotary evaporator.Dari pengujian skrining fitokimia ekstrak n-heksan kecombrang mengandung senyawa flavonoid, steroid dan saponin. Hal ini sesuai dengan penelitian yang dilakukan oleh Koraag et al. (2016) bahwa Kecombrang mengandung senyawa flavonoid, saponin, tannin, kuinon, monoterpen/ seskuiterpen, steroid / triterpenoid dan polifenolat. monoterpenoid dan seskuiterpenoid yang merupakan golongan senyawa penyusun minyak atsiri. Pelarut $n$-heksan dapat menarik senyawa-senyawa bersifat non polar seperti monoterpenoid dan seskuiterpenoid (Lestari, T, dkk, 2015).

Sereh wangi yang digunakan berasal dari Sereh segar yang diperoleh dari kota Bukittinggi. Sereh wangi di timbang sebanyak $1 \mathrm{~kg}$ kemudian dirajang lalu masukkan kedalam perkolator 
basahi dengan pelarut $n$-heksan sebanyak 1 liter, lakukan sebanyak 5 kali pengulangan. Filtrat yang didapatkan di uapkan dalam rotary evaporator.Dari pengujian skrining fitokimia ekstrak sereh wangi mengandung senyawa flavonoid, alkaloid dan saponin. Hal ini sesuai dengan penelitian yang dilakukan oleh Yulianita et al. (2019) bahwa sereh wangi mengandung senyawa flavonoid, alkaloid, saponin, polifenol, tannin, dan minyak atsiri.

Senyawa utama Sereh wangi adalah sitonellal, geraniol dan sitonellol.Sitronellol atau sering disebut dihydrogeraniol adalah suatu monoterpenoid alami yang diperoleh dari minyak sereh wangi. Senyawa-senyawa diatas memiliki peran yang sangat penting di bidang industri bahan baku farmasi, industri pangan, bahan baku parfum dan kosmetik. Senyawa dalam minyak Sereh wangi tidak hanya memberikan aromatik tetapi juga merupakan senyawa yang bersifat terapi (Bota, W, dkk., 2015).

Cengkeh yang digunakan berasal dari cengkeh segar yang diperoleh dari daerah Nagari Mahat Kab. 50 Kota. Dengan nama spesies Syzygium aromaticum. Cengkeh segar ditimbang sebanyak 350 gr kemudian dirajang lalu masukkan kedalam alat soxlet, kemudian lakukan soxhletasi sebanyak 20 kali siklus. Filtrat yang didapatkan di uapkan dalam rotary evaporator.Dari pengujian skirining fitokimia cengkeh mengandung senyawa flavonoid dan steroid. Hal ini sesuai dengan penelitian yang dilakukan oleh Widyarini et al. (2012) bahwa cengkeh mengandung senyawa sterol, fenol, flavonoid, polifenol, dan minyak atsiri. Komponen utama yang terkandung pada cengkeh adalah eugenol, kandungannya dapat mencapai 70-96\%.Semakin tinggi kandungan eugenolnya maka semakin baik kualitas dan nilai jualnya.Senyawa eugenol merupakan cairan bening hingga kuning pucat, dengan aroma menyegarkan dan pedas seperti bunga cengkeh kering, memberikan aroma yang khas pada minyak cengkeh, dimana senyawa ini banyak dibutuhkan oleh berbagai industri yang saat ini sedang berkembang. Aktivitas farmakologi eugenol antara lain sebagai analgesik, antiinflamasi, antimikroba, antiemetik, antiviral, antifungal, antiseptik, antispasmodik, stimulan, dan anastetik local, sehingga banyak dimanfaatkan oleh industri farmasi (Susilowati, E, P, dkk., 2014).

Heksana adalah suatu hidrokarbon alkana dengan rumus kimia $\mathrm{C}_{6} \mathrm{H}_{14} \cdot$ Heksana merupakan hasil refining minyak mentah.Komposisi dan fraksinya dipengaruhi oleh sumber minyak.Umumnya berkisar $50 \%$ dari berat rantai isomer dan mendidih pada $60-70^{\circ} \mathrm{C}$. Seluruh isomer heksana sering digunakan sebagai pelarut organik yang bersifat inert karena non polarnya.Banyak dipakai untuk ekstraksi minyak atsiri(Utomo, S, 2016).Karena pelarut n-heksan termasuk jenis pelarut organik non polar yang larut dalam bahan yang di ekstrak dan tidak larut dalam air seta mudah dipisahkan karena memiliki titik didih yang rendah (Gomarjoyo, H, dkk, 2015).

Formulasi sediaan dari ekstrak bunga kecombrang, sereh wangi dan cengkeh dibuat dalam bentuk lilin aromaterapi berdasarkan pertimbangan diantaranya lilin aroamaterapi bisa digunakan sebagai alternatif untuk media terapi atau untuk mengatur suasana hati, refresing, menyembuhkan sakit kepala, dan sebagai pewangi ruangan. Dan bisa digunakan untuk berbagai tujuan lainnya seperti menghilangkan stress dan kecemasan (Shofi, M, 2019). Senyawa pembentuk basis lilin yang digunakan pada penelitian ini adalah parafin padat, asam stearat dan ekstrak dari bunga kecombrang, sereh wangi, cengkeh (Fitri, K, dkk., 2020). Parafin padat adalah bahan baku utama dalam pembuatan lilin yang merupakan residu dari minyak bumi yang jika terbakar nyala apinya akan terang dan dapat meleleh pada suhu antara $40-70^{\circ} \mathrm{C}$ (Pati, T, M, 2015). Asam stearat merupakan campuran berbagai asam lemak jenuh dan asam lemak tidak jenuh, dengan komponen terbesar asam palmitat.Asam palmitat adalah asam lemak jenuh yang berbentuk padat pada suhu kamar. Penambahan asam stearat yang lebih banyak pada parafin akan membuat produk lilin lebih keras dan memiliki penampakan seperti kristal, karena asam stearat akan menjadi dominan dalam lilin dan menghasilkan lilin dengan struktur padat (Raharja, S, dkk, 2006).

Pada penelitian ini digunakan minyak atsiri dengan aroma yang berbeda-beda yaitu dari tumbuhan bunga kecombrang, sereh wangi, dan cengkeh.Jumlah ekstrak yang digunakan pada masing-masing formula adalah $1 \%$ dengan basis yang telah ditetapkan.Pembuatan lilin dengan konsentrasi $1 \%$ bertujuan untuk menghasilkan lilin dengan aroma yang tidak menyengat. 
Pembuatan sediaan lilin aromaterapi dengan minyak atsiri lebih dari $4 \%$, akan menghasilkan aroma yang tajam dan mengakibatkan efek pusing setelah satu jam (Raharja, S, dkk, 2006).

Lilin yang telah dibuat kemudian dilakukan evaluasi fisik untuk menentukan kualitas sediaan.Pemeriksaan organoleptis baik dalam hal bentuk, bau dan warna.Pada penelitian ini juga dilihat antara basis lilin dan formula ekstrak.F0 merupakan formula basis, sedangkan F1 - F3 merupakan formula esktrak.Perbedaan dari formula basis lilin dengan formula ekstrak adalah dari hal aroma sediaan.Hal ini dikarenakan aroma yang digunakan pada masing-masing formula berbeda.Yaitu F1 beraroma Kecombrang, F2 aroma sereh wangi, F3 aroma cengkeh.Dalam penelitian ini warna basis yang dihasilkan berwarna putih bersih, tetapi pada formula F2 berwarna kuning pucat.Hal ini dikarenakan penambahan ekstrak sereh wangi sehingga terjadi perubahan warna menjadi kuning pucat.

Uji waktu bakar menunjukkan waktu yang dibutuhkan sampai sumbu lilin habis (api padam). Hasil menunjukkan lilin F1 memiliki waktu bakar paling lama yaitu 1 jam 59 menit (119 menit), sementara waktu bakar paling cepat adalah lilin dengan formula F3 dengan lama waktu bakar 1 jam 27 menit (87 menit). Perbedaan waktu bakar lilin dipengaruhi oleh penambahan minyak atsiri, semakin tinggi kadar minyak atsiri semakin cepat lilin terbakar, karena sifat minyak atsiri yang mudah menguap ketika pembakaran lilin (Lestari, E, dkk., 2020). Menurut Djarot et al. (2019) lama waktu bakar lilin selain dari konsentrasi bahan aktif juga ditentukan oleh ukuran dan letak sumbu.Makin besar ukuran sumbu atau makin kepinggir letak sumbu lilin makin cepat habis. Waktu bakar lilin juga dipengaruhi oleh tinggi dan lebar lilin, karena semakin tinggi dan lebar lilin maka waktu bakarnya akan semakin lama, begitu juga sebaliknya.

Hasil pengujian titik leleh lilin dilakukan pada keempat formula yang menunjukkan titik leleh antara $48^{0} \mathrm{C}-51^{0} \mathrm{C}$. Kisaran titik leleh ini masih memenuhi syarat evaluasi sifat fisik lilin menurut SNI yaitu $42^{0} \mathrm{C}-60^{\circ} \mathrm{C}$. Titik leleh tertinggi yaitu formula $\mathrm{F} 351^{0} \mathrm{C}$. Titik leleh terendah yaitu formula F0 dan F1 $48^{\circ}$ C. Lilin formula F2 dan F3 memiliki titik leleh lebih tinggi dari formula F1 dan F0 dikarenakan penambahan minyak atsiri dalam pembuatan lilin aromaterapi dapat mempengaruhi titik leleh, semakin banyak penambahan minyak atsiri semakin tinggi suhu titik leleh lilinnya, karena sifat minyak atsiri yang mudah menguap ketika pembakaran lilin (Lestari, E, dkk., 2020). Titik leleh lilin juga dipengaruhi oleh titik leleh basis lilin yang digunakan.Apabila jumlah asam stearat yang digunakan lebih tinggi maka titik leleh lilin juga tinggi. Dimana titik leleh asam stearat menurut Farmakope edisi III yaitu $54^{0} \mathrm{C}$ sedangkan titik leleh parafin berkisar antara $42^{\circ} \mathrm{C}-60^{\circ} \mathrm{C}$. (Rusli, N, dkk., 2018).

Uji hedonik ini bertujuan untuk mengetahui tingkat kesukaan konsumen terhadap lilin aromaterapi yang dibuat. Dimana dengan pengujian ini diharapkan diperoleh data dari konsumen/ panelis terhadap tingkat kesukaan panelis terhadap lilin dengan berbagai perlakuan jenis pewangi alami dalam lilin tersebut (Rusli, N, dkk., 2018).

Dari data yang diperoleh, panelis lebih banyak menyukai aroma lilin Cengkeh dan lilin aroma Sereh wangi karena aromanya tidak terlalu tajam dibandingkan aroma bunga kecombrang karena pada minyak atsiri bunga kecombrang terdapat senyawa dodekanol yang merupakan senyawa yang paling banyak terdapat didalam minyak atsiri Kecombrang. Senyawa dodekanol berbentuk larutan yang berwarna kuning bening dengan aroma khas woody yang tajam. Biasa digunakan dalam penambahan aroma pada parfum, pewangi sabun, detergen, dan produk lainnya (Soetjipto, H, dkk., 2009).

\section{KESIMPULAN}

Berdasarkan penelitian yang telah dilakukan maka dapat diambil kesimpulan bahwa Ekstrak bunga kecombrang, sereh wangi, dan cengkeh dapat diformulasikan dalam bentuk sediaan lilin aromaterapi dengan konsentrasi zat berkhasiatnya $1 \%$.Dari data kesukaan, panelis lebih banyak menyukai aroma lilin cengkeh dan lilin aroma sereh wangi. 


\section{UCAPAN TERIMAKASIH}

Terimakasih kami ucapkan kepada seluruh pihak Akademi Farmasi Imam Bonjol yang telah memberikan bantuan dan motivasi terlaksananya penelitian ini.

\section{DAFTAR PUSTAKA}

Bota W. Martosupono, M. (2015). Potensi Senyawa Minyak Sereh Wangi (Citronella Oil) Dari Tumbuhan Cymbopogon nardus L. Sebagai Agen Antibakteri. Seminar Nasional Sains Dan Teknologi, 1-8.

Djarot P., Moerfiah., Ambarwati D. (2019). Lilin Aromatik Minyak Atsiri Kulit Batang Kayu Manis (Cinnamomum burmanii) Sebagai Repelen Lalat Rumah (Musca domestica). Jurnal Ilmiah Ilmu Dasar dan Lingkungan Hidup, 55-64.

Fitri, K., Hariz, I., Ginting, M., Safitri, N. (2020). Formula Kombinasi Minyak Nilam (Patchouli oil) Dan Minyak Mawar (Rose oil) Pada Sediaan Lilin Aromaterapi Relaksasi. Jurnal dunia farmasi Vol 4 No. 2, 90-98.

Gomarjoyo, H., Khomeini, A., Rahman, D., Sanjaya, A, S. (2015). Pengaruh Jenis Pelarut Terhadap Rendemen Minyak Sereh Wangi (Cymbopogon winterianus). Ekuilibrium Vol 14 No. 2, 57-61.

Kardian, A. (2005). Tanaman Penghasil Minyak Atsiri. Depok: Argomedia.

Lestari, E., Fatimah., Khotimah, K. (2020). Penggunaan Lilin Lebah Dengan Penambahan Konsentrasi Minyak Atsiri Tanaman Serai (Cymbopogon citratus) Sebagai Pengusir Lalat (Musca domestica). Agrium Vol 22 No. 3, 131-136.

Lestari, T., Ruswanto. (2015). Potensi Antikanker Dari Ekstrak Bunga Kecombrang Dengan Berebagai Tingkat Kepolaran Terhadap Sel T47D . Jurnal kesehatan balai tunas husada Vol 14 No. 1, 8-11.

Mukhriani. (2014). Ekstraksi Pemisahan Senyawa Dan Identifikasi Senyawa Aktif. jurnal kesehatan Vol 8 No. 2, 361-367.

Novita, W. (2009). Merawat Kecantikan Dirumah. Jakarta: Gramedia pustaka utama.

Pati, T. M. (2015). Farmakognosi 3. Yogyakarta: Deepublish.

Permadi, A. (2008). Membuat kebun tanaman obat. Jakarta: Pustaka bunda.

Rusli, M. S. (2010). Sukses Memproduksi Minyak Atsiri . Jakarta Selatan : Argomedia Pustaka .

Rusli, N., Rerung, Y, W, R. (2018). Formulasi Sediaan Lilin Aromaterapi sebagai Anti Nyamuk Dari Minyak Atsiri Daun Nilam (Pogostemon cablin Benth) Kombinasi Minyak Atsiri Buah Jeruk Nipis (Citrus aurantifolia Swingle).Jurnal Mandala Pharmacon Indonesia vol. 4 no.1, 68-73. 
Sandri, D., Fatimah., Adlhani, E., Erlinda, L. (2016). Optimasi Penambahan Minyak Atsiri Bunga Kamboja Terhadap Lilin Aromaterapi Dari Lilin Sarang Lebah. Jurnal teknologi agro industri Vol 3 No. 1, 1-7.

Shofi, M. (2019). Pemberdayaan Anggota PKK Melalui Pembuatan Lilin Aromaterapi. Jurnal of community engagement and employment Vol 1 No. 1, 40-46.

Soetjipto, H., Hastuti, S, P., Kristanto, O. (2009). Identifikasi Senyawa Antibakteri Minyak Atsiri Bunga Kecomrbrang (Nicolaia speciosa Horan). prosiding seminar nasional sains dan pendidikan sains Vol 4 No. 3, 640-655.

Susilowati, E, P., Wahyuningsih, S, S. (2014). Optimasi Sediaan Salep Yang Mengandung Eugenol Dari Isolasi Minyak Cengkeh (Eugenia caryophylatta Tunb.). Indonesian journal on medical science Vol 1 No. 2, 29-34.

Towaha, J. (2012). Manfaat Eugenol Cengkeh Dalam Berbagai Industri Di Indonesia. perspektif Vol 11 No. 2, 70-90.

Widyarini, A., Mariyah, Y., Ani, W, H, D. (2012). Perbandingan Efek Afrodiasiaka Infusa Dan Ekstrak N-Heksana Kuncup Bunga Cengkeh (Syzygium aromaticum L.) Pada Tikus Putih Jantan Galur Wistar. Jurnal Farmasi Indonesia Vol 9 No. 1, 9-15.

Yuliani, S., Satuhu, S. (2012). Panduan Lengkap Minyak Atsiri . Jakarta: Swadaya .

Yulianita, Y., Effendi, E, M., Firdayani, E, M. (2019). Efektivitas Sedatif Sereh Wangi (Cymbopogon nardus (L.) Rendle) terhadap Mencit Jantan (Musmusculus). Indonesian Journal of Pharmaceutical Science and Technology, 16-23.

Zuddin R, R., Abadi H., Khairani T, N. (2019). Pembuatan Dan Uji Hedonik Lilin Aromaterapi Dari Minyak Daun Mint (Mentha piperita L.) Dan Minyak Rosemary (Rosmarinus officinalis). Jurnal Dunia Farmasi Volume 3, Nomor 2, 79-90. 